\title{
Melatonin protects against arsenic trioxide-induced liver injury by the upregulation of Nrf2 expression through the activation of PI3K/AKT pathway
}

\author{
Yue Zhang ${ }^{1}$, Zhengkai Wei ${ }^{2}$, Weijian Liu ${ }^{2}$, Jingjing Wang ${ }^{2}$, Xuexiu He ${ }^{2}$, Hailong \\ Huang ${ }^{1}$, Jiali Zhang ${ }^{1}$ and Zhengtao Yang ${ }^{2}$ \\ ${ }^{1}$ College of Animal Science and Technology, Jilin Agricultural University, Changchun, People's Republic of China \\ 2 Department of Clinical Veterinary Medicine, College of Veterinary Medicine, Jilin University, Changchun, Jilin, People's \\ Republic of China \\ Correspondence to: Zhengtao Yang, email: yangzhengtao01@sina.com
}

Jiali Zhang, email: zhangjialijlau@163.com

Keywords: $\mathrm{As}_{2} \mathrm{O}_{3}$; melatonin; liver injury; $\mathrm{Nrf}-2$; Pathology Section

Received: April 09, $2016 \quad$ Accepted: October 29, 2016

Published: December 14, 2016

\section{ABSTRACT}

Melatonin has been demonstrated to have anti-inflammatory and antioxidant effects. The aim of this study was to investigate the protective effects of melatonin on arsenic trioxide $\left(\mathrm{As}_{2} \mathrm{O}_{3}\right)$-induced toxicity in liver and oxidative stress in rats. The

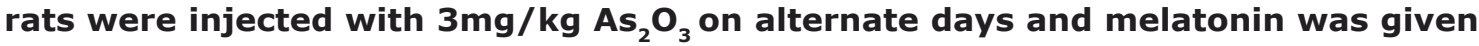
with an intraperitoneal injection (i.p.) $1 \mathrm{~h}$ before $\mathrm{As}_{2} \mathrm{O}_{3}$ treatment. On the 8th days, the rats were killed to determine liver histological injury, antioxidant activities and accumulation of arsenic in liver tissues. Our results showed that melatonin attenuated $\mathrm{As}_{2} \mathrm{O}_{3}$-induced hepatic pathological damage, liver parameters, liver ROS level, MDA level, and the retention of arsenic in liver tissues. Melatonin also improved the antioxidant enzymes SOD, GPX, and CAT activity induced by $\mathrm{As}_{2} \mathrm{O}_{3}$. Furthermore, melatonin improved the expression of $\mathrm{Nrf2}$ and HO-1. In addition, melatonin was found to activate PI3K/AKT pathway. In conclusion, our results indicated that melatonin protected against $\mathrm{As}_{2} \mathrm{O}_{3}$-induced liver injury by inducing $\mathrm{Nrf2/HO-1}$ expression via upregulation of PI3K/AKT pathway.

\section{INTRODUCTION}

Arsenic is a well-known global groundwater contaminant [1]. It often causes serious negative health effects in humans [2]. Exposure of human to arsenic results in toxicity and usually causes various types of solid tumors, such as bladder, skin, and lung cancers [3, 4]. Liver is the major target organ for many toxic chemicals, such as arsenic [5]. The mechanisms underlying arsenicinduced hepatotoxicity are not précised understood. However, most previous studies demonstrated that oxidative stress is the major contributor in arsenic trioxideinduced liver injury [6]. Arsenic exposure resulted in the development of oxidative stress-induced liver damage both in rats and humans [7]. Many investigators have confirmed that antioxidants could attenuate hepatotoxicity induced by arsenic [8]. Nrf2 is known to be involved in the regulation of oxidative stress and activation of $\mathrm{Nrf} 2$ could induce the expression of HO-1. Recently, studies showed that activation of $\mathrm{Nrf} 2$ could attenuate $\mathrm{As}_{2} \mathrm{O}_{3}-$ induced oxidative injury.

Melatonin, a secretory product of the pineal gland, has been reported to have anti-inflammatory and antioxidant effects [9]. Melatonin was found to inhibit neutrophil inflammation and mucus secretion in cigarette smoke-induced chronic obstructive pulmonary diseases [10]. Melatonin also inhibited LPS-induced inflammatory cytokines production in RAW264.7 cells [9]. Melatonin has been reported to reduce oxidative stress and preserve the fluidity of biological membranes [9]. Furthermore, melatonin has been reported to protect against metalcatalyzed molecular damage [11]. However, whether melatonin has protective effects on $\mathrm{As}_{2} \mathrm{O}_{3}$-induced toxicity in liver and oxidative stress in rats remains unclear. Therefore, we investigated the protective effects of melatonin against arsenic trioxide-induced liver injury. 


\section{RESULTS}

\section{Melatonin inhibits As2O3-induced ALT and AST levels in serum}

The effects of melatonin on $\mathrm{As}_{2} \mathrm{O}_{3}$-induced ALT and AST levels in serum were determined in this study. The results showed that $\mathrm{As}_{2} \mathrm{O}_{3}$ significantly up-regulated the production of ALT and AST. Treatment of melatonin dose-dependently inhibited $\mathrm{As}_{2} \mathrm{O}_{3}$-induced ALT and AST production (Figure 1).

\section{Melatonin inhibits As2O3-induced ROS and MDA levels}

The effects of melatonin on $\mathrm{As}_{2} \mathrm{O}_{3}$-induced ROS and MDA levels were used to assess the antioxidant effects of melatonin. As shown in Figure 2, the levels of ROS and MDA in liver tissues were significantly increased after $\mathrm{As}_{2} \mathrm{O}_{3}$ treatment. However, the production of ROS and MDA were suppressed by melatonin in a dose-dependently manner (Figure 2).

\section{Melatonin up-regulated the activity of antioxidant enzymes SOD, GPX, and CAT}

Antioxidant enzymes SOD, GPX, and CAT were used to assess the antioxidant effects of melatonin. In this study, our results showed that the levels of SOD, GPX, and $\mathrm{CAT}$ decreased in $\mathrm{As}_{2} \mathrm{O}_{3}$-treated group when compared with the control group. However, melatonin up-regulated the production of SOD, GPX, and CAT inhibited by $\mathrm{As}_{2} \mathrm{O}_{3}$ (Figure 3)
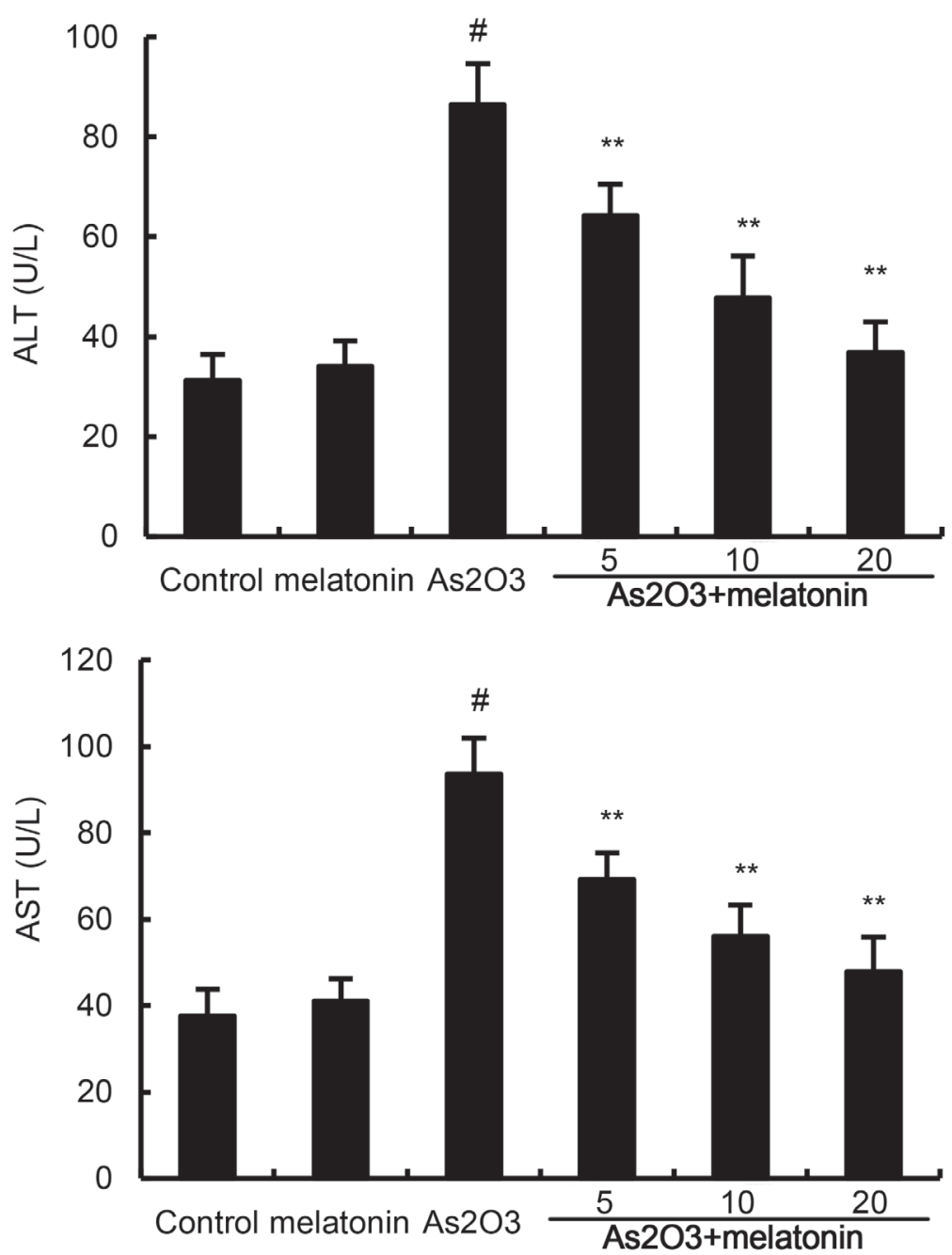

Figure 1: Effects of melatonin on $\mathrm{As}_{2} \mathbf{O}_{3}$-induced ALT and AST levels. The values presented are the means $\pm \operatorname{SEM}(n=12$ in each group). $\# p<0.01 v s$. control group, ${ }^{*} p<0.05$ and ${ }^{* *} p<0.01 v s . \mathrm{As}_{2} \mathrm{O}_{3}$ group. 


\section{Melatonin attenuated As2O3-induced liver} histopathologic changes

To assess the protective effects of melatonin on $\mathrm{As}_{2} \mathrm{O}_{3}$-induced liver injury, liver tissues histopathologic changes were detected. As shown in Figure 4, liver tissues of control and melatonin-treated groups showed a normal structure. Liver sections of $\mathrm{As}_{2} \mathrm{O}_{3}$-treated group showed severe pathologic changes, including extensive areas of portal inflammation, inflammatory cell infiltration and cellular necrosis. These pathological changes of liver sections were reduced by treatment of melatonin (Figure $4 \mathrm{D}, 4 \mathrm{E}, 4 \mathrm{~F})$.
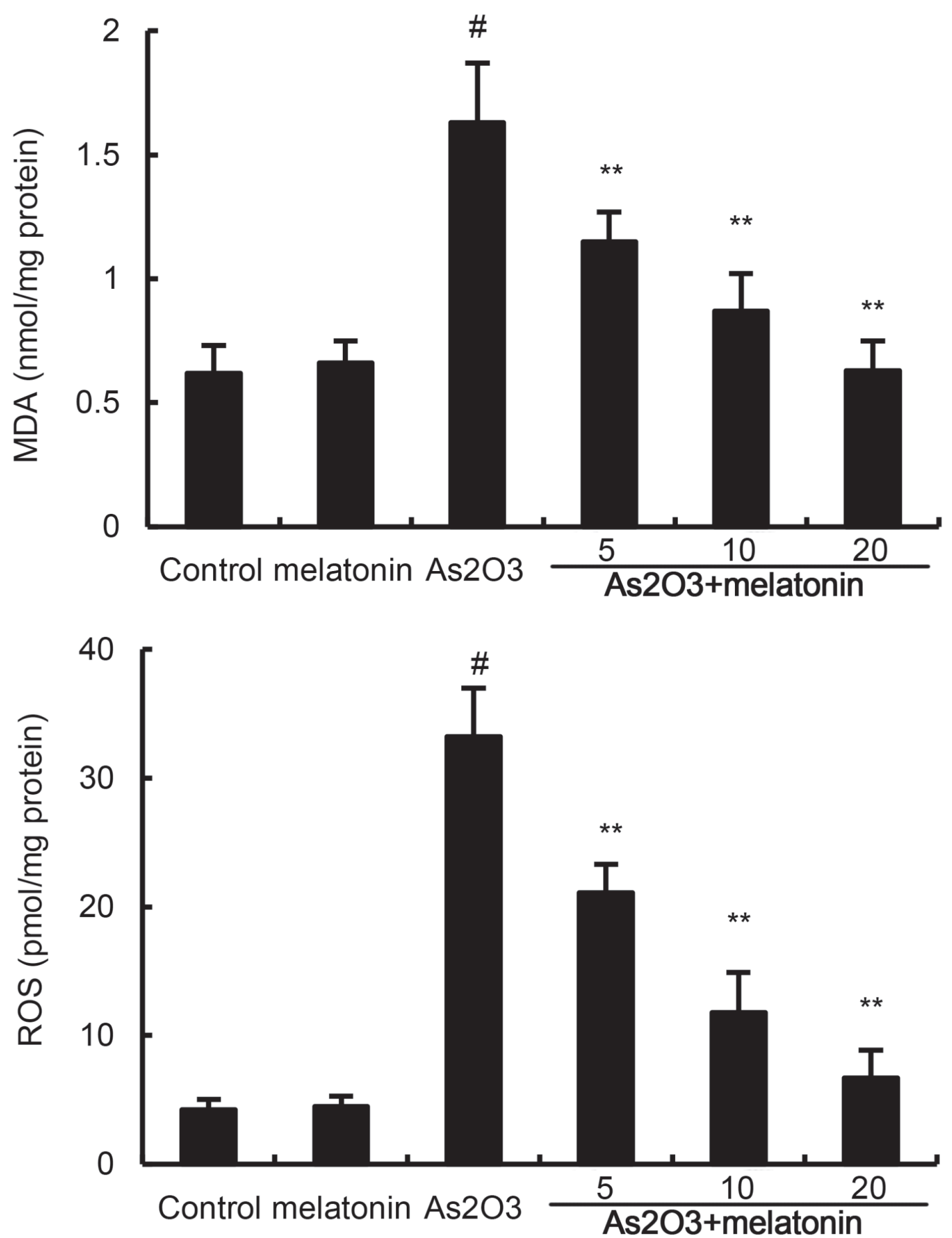

Figure 2: Effects of melatonin on $\mathrm{As}_{2} \mathrm{O}_{3}$-induced ROS and MDA levels. The values presented are the means $\pm \operatorname{SEM}(n=12$ in each group). $\# p<0.01$ vs. control group, ${ }^{*} p<0.05$ and ${ }^{* *} p<0.01 v s$. $\mathrm{As}_{2} \mathrm{O}_{3}$ group. 

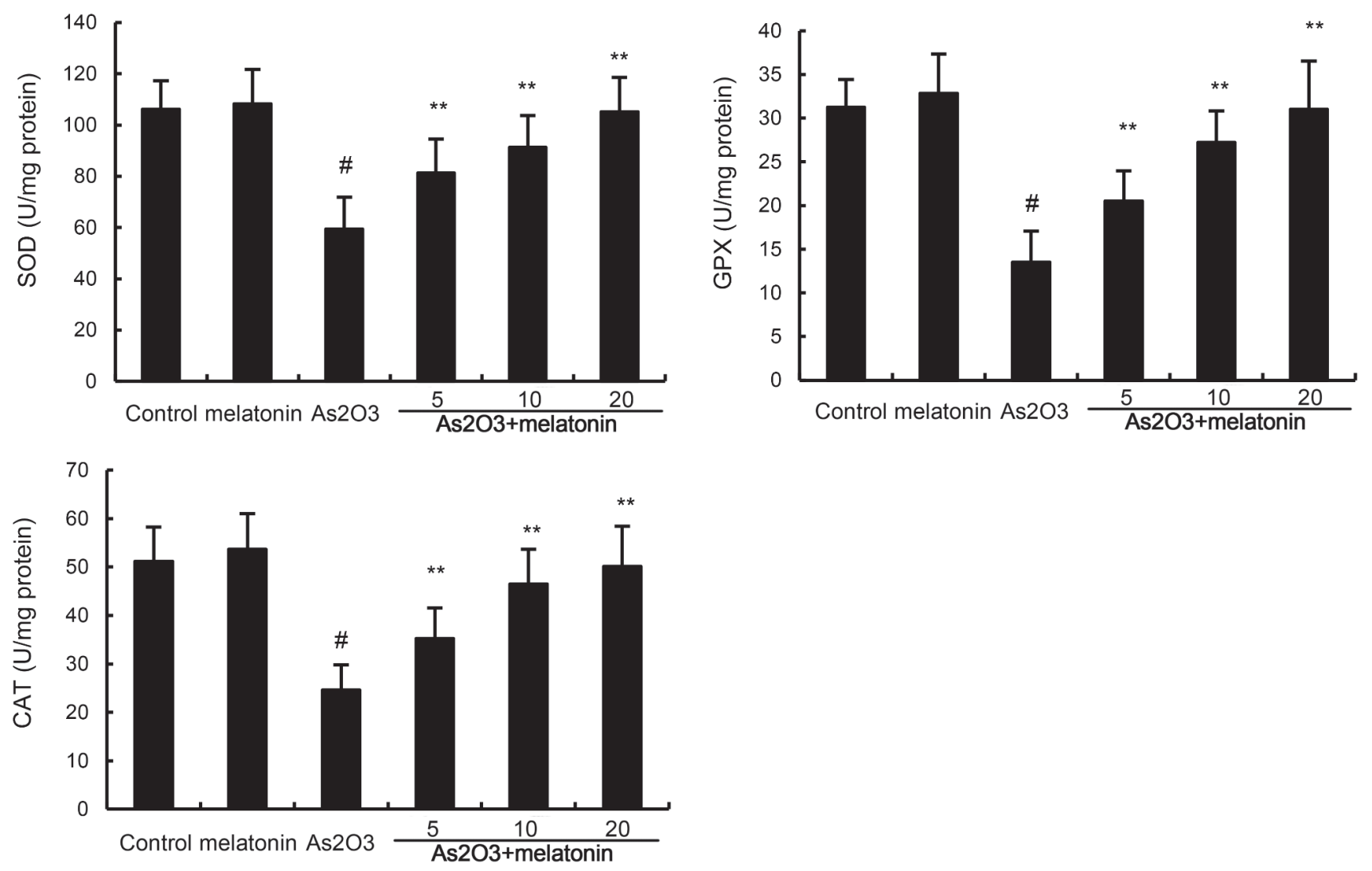

Figure 3: Effects of melatonin on $\mathrm{As}_{2} \mathrm{O}_{3}$-induced antioxidant enzymes SOD, GPX, and CAT activity. The values presented are the mean $\pm \operatorname{SEM}\left(n=12\right.$ in each group). $p \#<0.01 v s$. control group, $p^{*}<0.05, p^{* *}<0.01 v s . \mathrm{As}_{2} \mathrm{O}_{3}$ group.
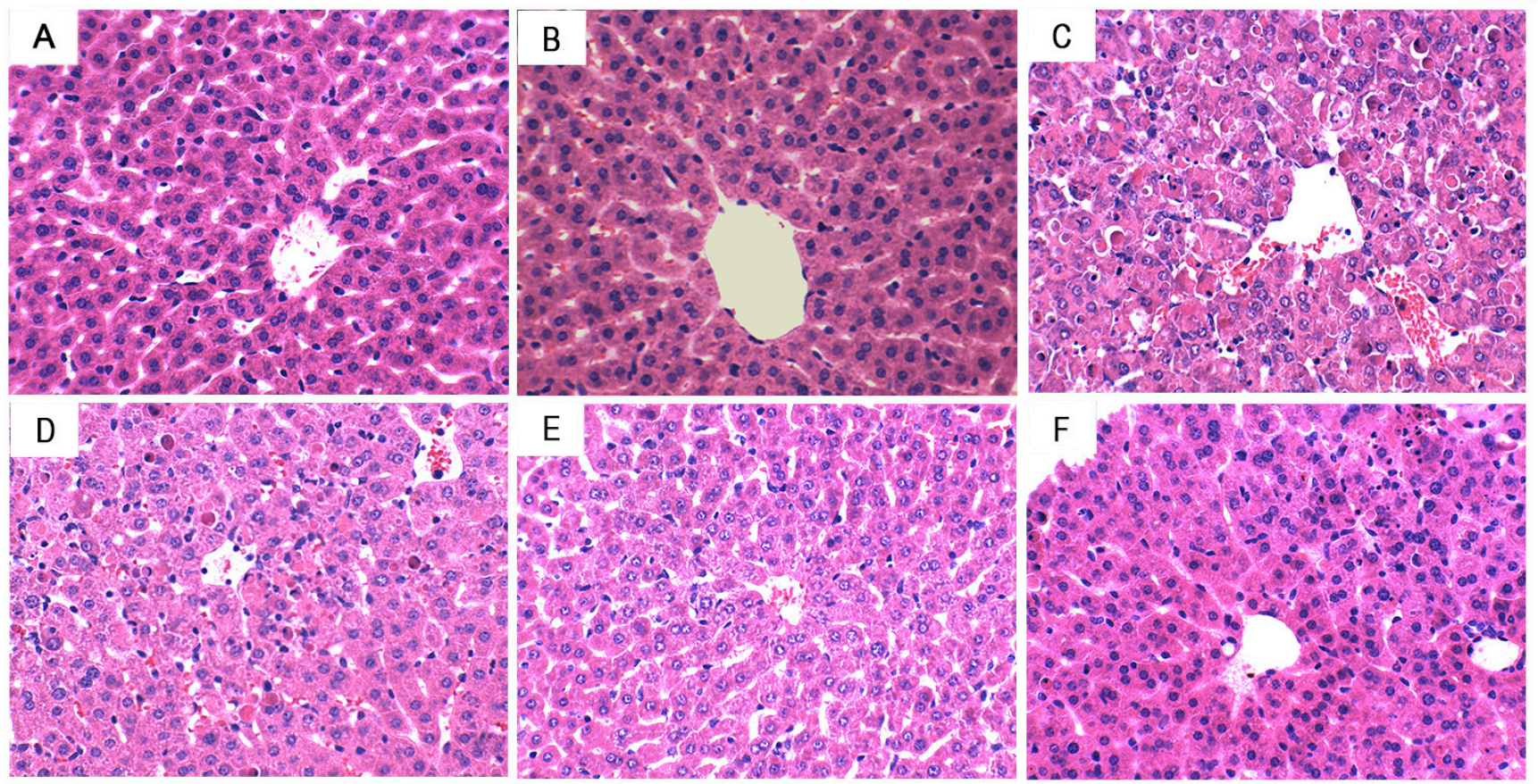

Figure 4: Effects of melatonin on $\mathrm{As}_{2} \mathrm{O}_{3}$-induced liver histopathologic changes. Representative histological changes of liver obtained from mice of different groups. A. Control group, B. melatonin $(20 \mathrm{mg} / \mathrm{kg})$ group, C. $\mathrm{As}_{2} \mathrm{O}_{3}$ group, D. melatonin $(5 \mathrm{mg} / \mathrm{kg})+\mathrm{As}_{2} \mathrm{O}_{3}$ $\left(50 \mathrm{mg} / \mathrm{kg}\right.$ ) group, E. melatonin $(10 \mathrm{mg} / \mathrm{kg})+\mathrm{As}_{2} \mathrm{O}_{3}(50 \mathrm{mg} / \mathrm{kg})$ group, F: melatonin $(20 \mathrm{mg} / \mathrm{kg})+\mathrm{As}_{2} \mathrm{O}_{3}(50 \mathrm{mg} / \mathrm{kg})$ group (Hematoxylin and eosin staining, magnification $200 \times)$. 


\section{Melatonin attenuated the retention of arsenic in liver tissues}

The effects of melatonin on the retention of arsenic in liver tissues were detected in this study. As shown in Figure $5, \mathrm{As}_{2} \mathrm{O}_{3}$ resulted in a significant increase in the arsenic concentration of liver tissues. However, melatonin dose-dependently inhibited $\mathrm{As}_{2} \mathrm{O}_{3}$-induced accumulation of arsenic in liver tissues (Figure 5).

\section{Effects of melatonin on Nrf2 and HO-1 expression}

To investigate the protective mechanism of melatonin, the effects of melatonin on Nrf2 and HO-1 expression were detected by western blotting. The results showed that nuclear translocation of Nrf2 and HO-1 expressions were increased by $\mathrm{As}_{2} \mathrm{O}_{3}$. These increases in Nrf2 and HO-1 expression were up-regulated by melatonin (Figure 6).

\section{Effects of melatonin on PI3K/AKT pathway}

The effects of melatonin on PI3K/AKT pathway were detected by western blotting. The results showed that $\mathrm{As}_{2} \mathrm{O}_{3}$ decreased the phosphorylation of PI3K and AKT. However, our results showed that melatonin upregulated the phosphorylation of PI3K and AKT (Figure 7).

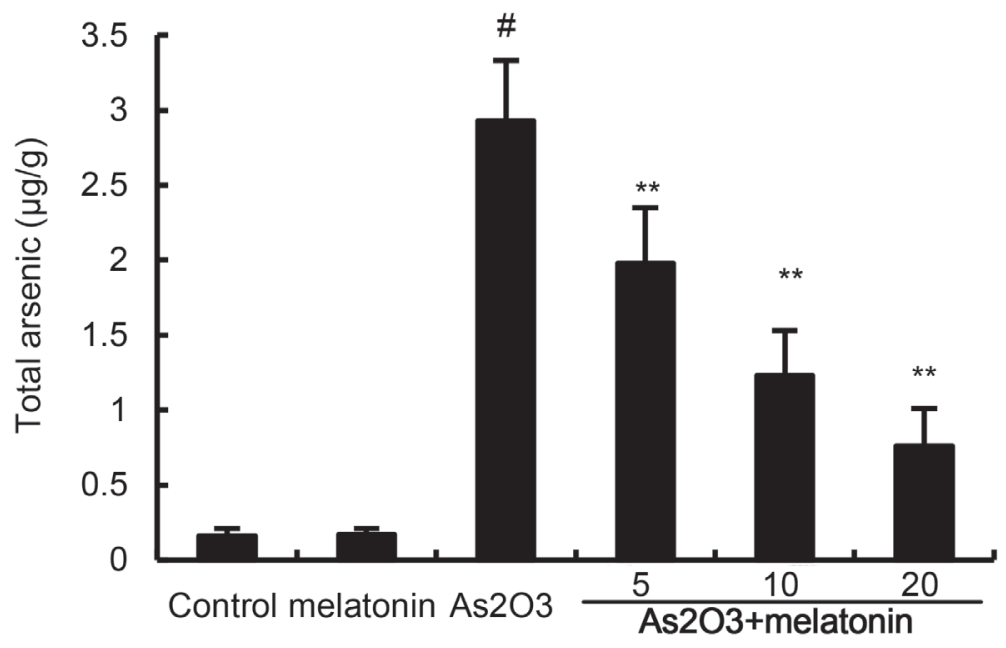

Figure 5: Effects of melatonin on As accumulation in liver tissues. The values presented are the means \pm SEM $(n=12$ in each group). $\# p<0.01$ vs. control group, ${ }^{*} p<0.05$ and ${ }^{* *} p<0.01$ vs. $\mathrm{As}_{2} \mathrm{O}_{3}$ group.
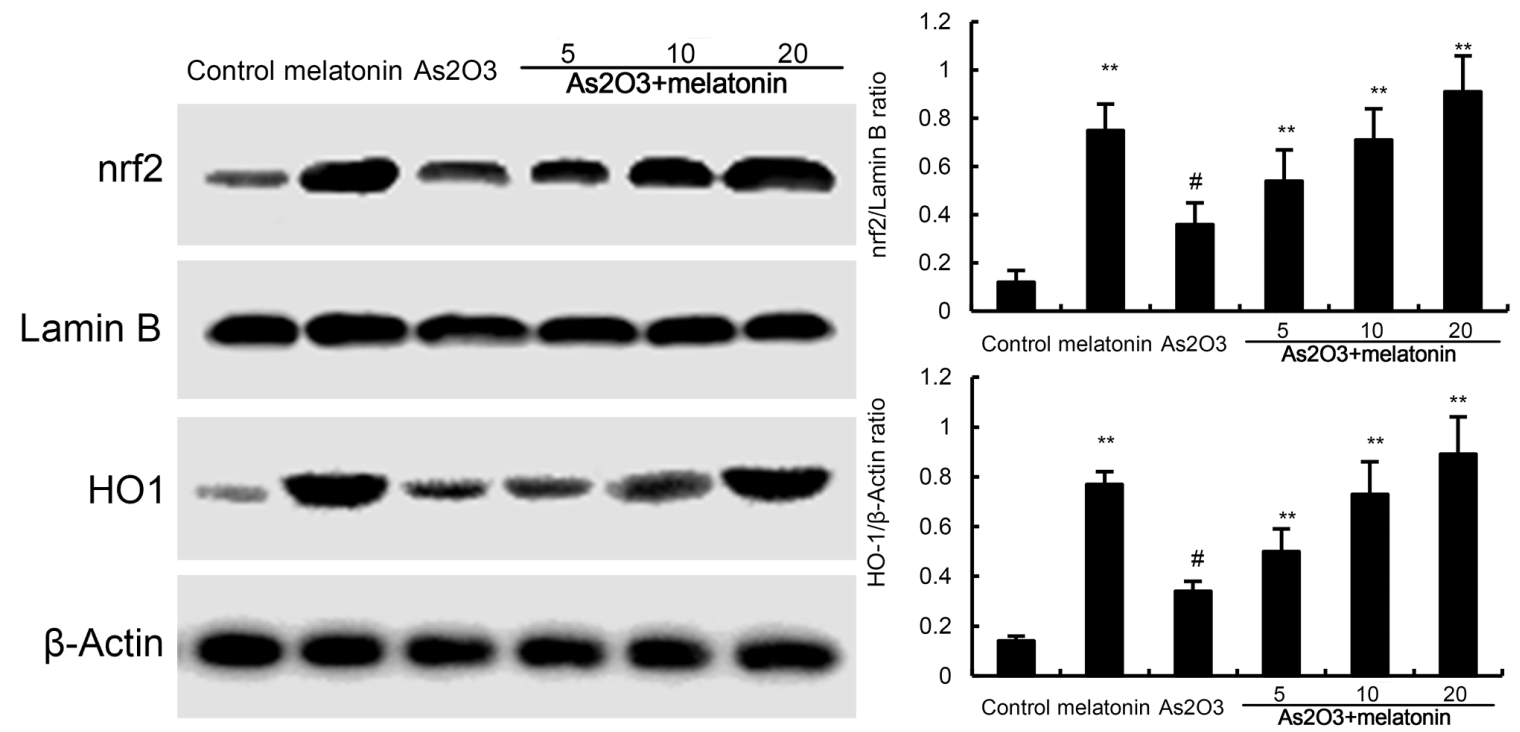

Figure 6: Effects of melatonin on Nrf2 and HO-1 expression. The values presented are the means $\pm \operatorname{SEM}(n=12$ in each group). $\# p<0.01$ vs. control group, ${ }^{*} p<0.05$ and $* * p<0.01$ vs. $\mathrm{As}_{2} \mathrm{O}_{3}$ group. 


\section{DISCUSSION}

Arsenic, a well-known global groundwater contaminant, has been reported to cause severe health hazards [12]. In this study, we investigate the protective effects of melatonin on $\mathrm{As}_{2} \mathrm{O}_{3}$-induced liver injury in rats. Our results demonstrated that melatonin protected against $\mathrm{As}_{2} \mathrm{O}_{3}$-induced liver injury by reducing the retention of arsenic in liver tissues and activating of Nrf2 signaling pathway.

Previous studies showed that arsenic exposure resulted in the development of oxidative stress-induced liver damage both in rats and humans [13]. The generation of ROS after arsenic exposure has been reported to play a fundamental role in the induction of adverse health effects and disease [14]. MDA, an indicator of oxidant status, was used to assess the oxidative stress [15]. To determine oxidant stress, we measured ROS and MDA in liver tissues. Our results showed that treatment of $\mathrm{As}_{2} \mathrm{O}_{3}$ significantly increased the production of ROS and MDA in liver tissues. Melatonin dose-dependently inhibited $\mathrm{As}_{2} \mathrm{O}_{3}$-induced $\mathrm{ROS}$ and MDA production. In addition, melatonin was found to up-regulate the production of SOD, GPX, and CAT inhibited by $\mathrm{As}_{2} \mathrm{O}_{3}$ Recent studies showed that the antioxidants could be used as preventive and therapeutic agents against oxidative damage occurring during arsenic exposure [16, 17]. In this study, we found that melatonin attenuated $\mathrm{As}_{2} \mathrm{O}_{3}$-induced liver histopathologic changes. These results suggested that melatonin protected against $\mathrm{As}_{2} \mathrm{O}_{3}$-induced liver injury by inhibiting oxidative stress.

$\mathrm{Nrf2}$ is a key transcription factor that binds and activates the antioxidant response element (ARE) in the promoters of many antioxidant genes $[18,19]$. Nrf2 is known to play a key role in orchestrating cellular antioxidant defenses and emerging data suggested that constitutive activation of $\mathrm{Nrf} 2$ had protective effects against $\mathrm{As}_{2} \mathrm{O}_{3}$-induced tissue injury $[20,21]$. To investigate the antioxidant mechanism of melatonin, the effects of melatonin on Nrf-2 and HO-1 expression were detected by western blot analysis. The results showed that nuclear translocation of Nrf2 and HO-1 expressions were increased by melatonin. These increases in Nrf2 and HO-1 expressions were amplified by melatonin. These results suggested that melatonin exhibited antioxidant effects by activating Nrf2 signaling pathway. Previous research has demonstrated that the PI3K/AKT pathway plays a critical role in modulating Nrf2/HO-1 protein expression as an upstream signaling molecule [22]. In this study, we found melatonin upregulated the phosphorylation of PI3K and AKT. These results suggested that melatonin protected against $\mathrm{As}_{2} \mathrm{O}_{3}$-induced liver injury by inducing Nrf2/HO-1 expression via upregulation of PI3K/AKT pathway.

In conclusion, the results of this study showed that melatonin had a protective effect on $\mathrm{As}_{2} \mathrm{O}_{3}$-induced liver injury. Melatonin protected against $\mathrm{As}_{2} \mathrm{O}_{3}$-induced liver injury by the maintenance of redox homeostasis by inducing Nrf2/HO-1 expression via upregulation of PI3K/ AKT pathway. These evidences suggested that melatonin had a potential application to treat $\mathrm{As}_{2} \mathrm{O}_{3}$-induced liver injury.

\section{MATERIALS AND METHODS}

\section{Materials}

$\mathrm{As}_{2} \mathrm{O}_{3}$ parenteral solution $(10 \mathrm{mg} / \mathrm{ml})$ was purchased from Harbin Yida Pharmaceutical Company Ltd. (Harbin, China). Determination kits of ROS, GPX, SOD, CAT, and
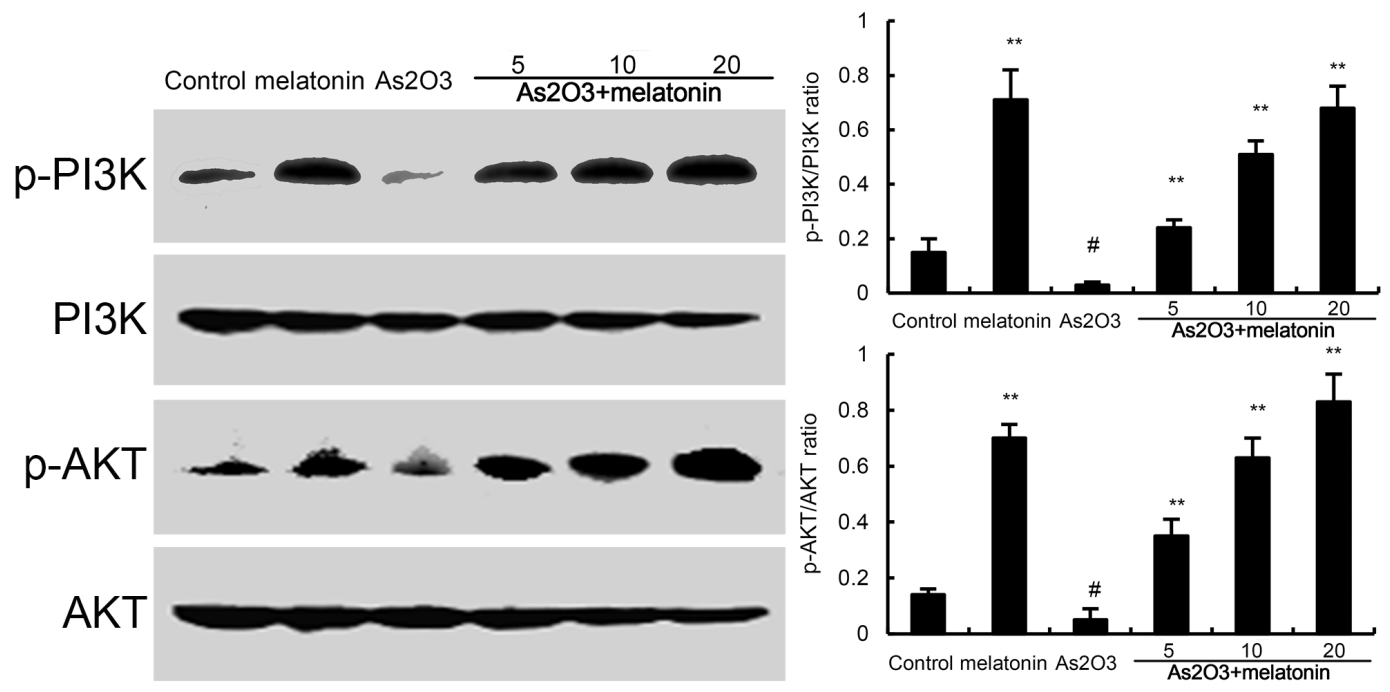

Figure 7: Effects of melatonin on PI3K/AKT phosphorylation. The values presented are the means \pm SEM $(n=12$ in each group). $\# p<0.01 v s$. control group, ${ }^{*} p<0.05$ and $* * p<0.01 v s . \mathrm{As}_{2} \mathrm{O}_{3}$ group. 
MDA were purchased from the Jiancheng Bioengineering Institute of Nanjing (Nanjing, Jiangsu, China). Antibodies specific for Nrf2, HO-1, Lamin B, $\beta$-actin, and horseradish peroxidase-conjugated (HRP) secondary antibodies were purchased from Santa Cruz Biotechnology (Autogen, Bioclear, UK). Melatonin (purity $>98 \%$ ) and all other chemicals were purchased from Sigma Aldrich (St. Louis, MO, USA).

\section{Animals}

Male Wistar rats (8-9 week) were purchased from the Center of Experimental Animals of Jilin University (Changchun, China). The rats were kept in an environmentally controlled environment (temperature: $25 \pm 2{ }^{\circ} \mathrm{C}$; humidity: $60 \pm 5 \%, 12$-h dark/light cycle). Water and pellet diets were supplied ad libitum. All animal experiments were approved by the NIH Guide for the Care and Use of Laboratory Animals.

\section{Experimental protocol}

72 male Wistar rats were randomly divided into six groups and each group contains 12 rats: control group, melatonin treatment group, $\mathrm{As}_{2} \mathrm{O}_{3}$ group, and $\mathrm{As}_{2} \mathrm{O}_{3}+$ melatonin treatment group.

Control group: rats were treated with equal amount of $0.9 \%$ normal saline as a vehicle control.

Melatonin treatment group: rats were given by an intraperitoneal injection of melatonin $(20 \mathrm{mg} / \mathrm{kg})$ once a day for 8 days.

$\mathrm{As}_{2} \mathrm{O}_{3}$ group: rats were administrated $3 \mathrm{mg} / \mathrm{kg} \mathrm{As} \mathrm{As}_{3}$ intravenous injection on alternate days for 4 days.

$\mathrm{As}_{2} \mathrm{O}_{3}+$ melatonin $(5 \mathrm{mg} / \mathrm{kg})$ treatment group: rats were given by an intraperitoneal injection of melatonin $(5 \mathrm{mg} / \mathrm{kg})$ once a day for 8 days.

$\mathrm{As}_{2} \mathrm{O}_{3}+$ melatonin $(10 \mathrm{mg} / \mathrm{kg})$ treatment group: rats were given by an intraperitoneal injection of melatonin $(10 \mathrm{mg} / \mathrm{kg})$ once a day for 8 days.

$\mathrm{As}_{2} \mathrm{O}_{3}+$ melatonin $(20 \mathrm{mg} / \mathrm{kg})$ treatment group: rats were given by an intraperitoneal injection of melatonin $(20 \mathrm{mg} / \mathrm{kg})$ once a day for 8 days.

On the 8 th day, the rats were killed and the blood samples and livers from each group were collected for various biochemical analyses.

\section{Histological analysis}

$24 \mathrm{~h}$ after the last time of $\mathrm{As}_{2} \mathrm{O}_{3}$ treatment, the livers were collected. Liver tissues were fixed in $10 \%$ formalin, embedded in paraffin, and sliced. After hematoxylin and eosin (H\&E) staining, histopathological changes were visualized with a microscope (Olympus, Japan).

\section{Measurement of oxidative stress and antioxidant enzymes in liver tissues}

The levels of ROS, MDA, the antioxidant enzymes SOD, GPX, and CAT in liver tissues were detected by using commercial kits purchased from the Jiancheng Bioengineering Institute of Nanjing according to the manufacturer's instructions (Nanjing, Jiangsu, China).

\section{Measurement of ALT and AST}

The ALT and AST levels in serum were detected by using test kits purchased from the Jiancheng Bioengineering Institute of Nanjing (Nanjing, Jiangsu, China) according to the manufacturer's instructions.

\section{Measurement of total arsenic in the liver}

$24 \mathrm{~h}$ after the last time of $\mathrm{As}_{2} \mathrm{O}_{3}$ treatment, the livers were collected. Then liver tissues were digested in $\mathrm{HNO}_{3}-\mathrm{HCLO}_{4}$ solution at $130^{\circ} \mathrm{C}$ for 2 days. After diluted with deionized water, the concentrations of arsenic in liver tissues were measured using atomic fluorescence spectrometry.

\section{Western blot analysis}

Liver tissues were homogenized and total proteins were extracted using T-PER Tissue Protein Extraction Reagent Kit according to the manufacturer's instructions (Thermo Scientific, MA, USA). The protein concentration was determined through BCA method. $50 \mu \mathrm{g}$ proteins per lane were separated by $12 \%$ SDS-PAGE gel. Then the proteins were transferred onto PVDF membranes. After blocking the nonspecific site with 5\% nonfat dry milk, the membranes were probed with specific primary antibody at $4{ }^{\circ} \mathrm{C}$ overnight. The membranes were incubated with secondary antibodies. Finally, the membranes were washed with PBS-T and then developed with the ECL Plus Western Blotting Detection System (Amersham Life Science, UK).

\section{Statistical analysis}

Data are presented as mean \pm SEM of three separate experiments. Comparison between groups was made with ANOVA followed by Dunnett's test. The $\mathrm{P}<0.05$ was considered statistically significant.

\section{CONFLICTS OF INTERESTS}

The authors have no conflict of interest to declare. 


\section{GRANT SUPPORT}

This work was supported by a grant from the National Natural Science Foundation of China (C180802).

\section{REFERENCES}

1. Mukherjee A, Sengupta MK, Hossain MA, Ahamed S, Das B, Nayak B, Lodh D, Rahman MM and Chakraborti D. Arsenic contamination in groundwater: a global perspective with emphasis on the Asian scenario. Journal of Health, Population and Nutrition. 2006; 24(2):142-163.

2. Kapaj S, Peterson H, Liber K and Bhattacharya P. Human health effects from chronic arsenic poisoning-a review. Journal of Environmental Science and Health Part A. 2006; 41(10):2399-2428.

3. Jomova K, Jenisova Z, Feszterova M, Baros S, Liska J, Hudecova D, Rhodes C and Valko M. Arsenic: toxicity, oxidative stress and human disease. J Appl Toxicol. 2011; 31(2):95-107.

4. Moore LE, Smith AH, Eng C, Kalman D, DeVries S, Bhargava V, Chew K, Moore II D, Ferreccio C and Rey OA. Arsenic-related chromosomal alterations in bladder cancer. Journal of the National Cancer Institute. 2002; 94(22):1688-1696.

5. Acosta D, Sorensen EM, Anuforo DC, Mitchell DB, Ramos $\mathrm{K}$, Santone KS and Smith MA. An in vitro approach to the study of target organ toxicity of drugs and chemicals. In vitro cellular \& developmental biology. 1985; 21(9):495504.

6. Mershiba SD, Dassprakash MV and Saraswathy SD. Protective effect of naringenin on hepatic and renal dysfunction and oxidative stress in arsenic intoxicated rats. Molecular biology reports. 2013; 40(5):3681-3691.

7. Chattopadhyay S, Maiti S, Maji G, Deb B, Pan B and Ghosh D. Protective role of Moringa oleifera (Sajina) seed on arsenic-induced hepatocellular degeneration in female albino rats. Biological trace element research. 2011; 142(2):200-212.

8. Paul MK, Kumar R and Mukhopadhyay AK. Dithiothreitol abrogates the effect of arsenic trioxide on normal rat liver mitochondria and human hepatocellular carcinoma cells. Toxicology and applied pharmacology. 2008; 226(2):140152.

9. Xia MZ, Liang YL, Wang H, Chen X, Huang YY, Zhang ZH, Chen YH, Zhang C, Zhao M, Xu DX and Song LH. Melatonin modulates TLR4-mediated inflammatory genes through MyD88- and TRIF-dependent signaling pathways in lipopolysaccharide-stimulated RAW264.7 cells. Journal of pineal research. 2012; 53:325-334.

10. Shin IS, Shin NR, Park JW, Jeon CM, Hong JM, Kwon OK, Kim JS, Lee IC, Kim JC, Oh SR and Ahn KS. Melatonin attenuates neutrophil inflammation and mucus secretion in cigarette smoke-induced chronic obstructive pulmonary diseases via the suppression of Erk-Sp1 signaling. J Pineal Res. 2015; 58(1):50-60.

11. Romero A, Ramos E, de Los Rios C, Egea J, Del Pino J and Reiter RJ. A review of metal-catalyzed molecular damage: protection by melatonin. J Pineal Res. 2014; 56(4):343-370.

12. Saha J, Dikshit A, Bandyopadhyay M and Saha K. A review of arsenic poisoning and its effects on human health. Critical reviews in environmental science and technology. 1999; 29(3):281-313.

13. Bagnyukova TV, Luzhna LI, Pogribny IP and Lushchak VI. Oxidative stress and antioxidant defenses in goldfish liver in response to short $\square$ term exposure to arsenite. Environmental and molecular mutagenesis. 2007; 48(8):658-665.

14. Ding W, Hudson LG and Liu KJ. Inorganic arsenic compounds cause oxidative damage to DNA and protein by inducing ROS and RNS generation in human keratinocytes. Mol Cell Biochem. 2005; 279(1-2):105-112.

15. Urso ML and Clarkson PM. Oxidative stress, exercise, and antioxidant supplementation. Toxicology. 2003; 189(1):4154.

16. Flora S, Mittal M and Mehta A. Heavy metal induced oxidative stress \& its possible reversal by chelation therapy. Indian Journal of Medical Research. 2008; 128(4):501.

17. Kalia K and Flora SJ. Strategies for safe and effective therapeutic measures for chronic arsenic and lead poisoning. Journal of occupational health. 2005; 47(1):1-21.

18. Kwak M-K, Itoh K, Yamamoto $M$ and Kensler TW. Enhanced expression of the transcription factor Nrf2 by cancer chemopreventive agents: role of antioxidant response element-like sequences in the nrf2 promoter. Molecular and cellular biology. 2002; 22(9):2883-2892.

19. Jaiswal AK. Nrf2 signaling in coordinated activation of antioxidant gene expression. Free Radical Bio Med. 2004; 36(10):1199-1207.

20. Zhang W, Guo C, Gao R, Ge M, Zhu Y and Zhang Z. The protective role of resveratrol against arsenic trioxideinduced cardiotoxicity. Evid-Based Compl Alt. 2013; 2013.

21. Lee J-M and Johnson JA. An important role of Nrf2-ARE pathway in the cellular defense mechanism. BMB Reports. 2004; 37(2):139-143.

22. Reddy NM, Potteti HR, Vegiraju S, Chen HJ, Tamatam CM and Reddy SP. PI3K-AKT Signaling via Nrf2 Protects against Hyperoxia-Induced Acute Lung Injury, but Promotes Inflammation Post-Injury Independent of Nrf2 in Mice. Plos One. 2015; 10(6):e0129676. 